\title{
カンボジア農村におけるリスクシェアリング制度 ーサンガハと葬儀組合の比較ー
}

\section{1.はじめに}

カンボジア農村には，家計の直面するリスクに対処 するための村レベルのリスクシェアリング制度が存在 する. その代表が葬儀組合とサンガ八である. カンボ ジアでは葬儀に多額の費用がかかるが，葬儀組合は， 家計の葬儀費用負担を軽減するために葬儀を出す家に 香典とは別に村ぐるみで寄付をする仕組みである。

方，サンガ八は主に重い病気の治療費のために経済的 に困窮した家に対して村ぐるみで寄付をする制度であ る。その背景には, カンボジアでは家計の医療費負担 が非常に大きいという問題がある。それは国による医 療部門への財政的支援がそしいということ，そして公 的な医療保険制度が存在しない, ということの結果で ある．カンボジアでは医療費捻出のために高利で借金 をしたり土地を売ることは珍しくなく，医療費負担が 農村家計の経済的没落の主要な要因の一つも考えら れている。サンガ八はこのような問題を緩和するため の制度である。

カンボジアでは国による公的なリスクシェアリング 制度の整備が近い将来期待できないので，国民は当面 はインフォーマルな制度に頼るしかない，そこでイン

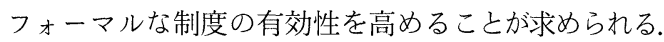
しかし，サンガ八を通じて集まる寄付は一般に少なく， 高額の医療費をまかなうには不十分である。そしてそ の一因は，サンガ八の多くで寄付が任意となっている ことにあると考えられる．これは大半の葬儀組合で寄 付が義務化されていることと対照的である.

そこで本稿は，サンガ八と葬儀組合の仕組みとそれ を支える論理を明らかにし， サンガ八で寄付の義務化 がなされにくい原因と寄付義務化のために考慮すべき 点を探る.

ここでの分析に用いるデー夕は，報告者が 2003 年 1 月から 2 月にかけて行った調査で得られた。調査対 象は夕カエウ州の計 19 村における 9 の葬儀組合と 18 のサンガ八である11.

\section{2. 仕組み}

(1) サンガ八・葬儀組合の仕組みと利点 サンガ八は一般に次のようにして営まれる。 (1)村民
のなかに重病人（ないし重傷者）が出る(2)運営者が村 民に寄付を呼びかる(3)村の各世帯は病人に対して直接 寄付をする (寄付は世帯単位)。葬儀組合の仕組みは これにほぼ同じで，次のように営まれる。(1)村民の中 に死者がでる(2)運営者が村民に寄付を呼びかける(3)葬 儀の準備段階で村の各世帯は葬儀を出す家に直接寄付 をする。

サンガ八や葬儀組合は調查対象地域一帯で広く見ら れるが，実はリスク対処メカニズムとしては例外的で ある。一般には，人々は資産売却，借入，贈与などに よってリスクに対処している。しかしそれらの対処方 法には問題ないし限界がある.

資産売却は，それがとくに生産用資産の場合には家 計の将来の所得を減少させる。また資産に之しい家計 の場合, 資産売却は選択肢之ならない。借入の問題は, 第 1 にカンボジア農村では利子つきのローンが多くそ の利子率が非常に高いことだ。カンボジア農村家計の 主要な借入先は富裕な農家や商人といったインフォー マルな貸手であるが，その利子率は一般に月 $10 \%$ と 高い，親戚や親しい友人からは無利子で借りられる場 合が多いが，無利子で借りられるかどうかは無利子で 貸してくれる余裕のある親戚・友人がいるかどうかに かかっている．借入の第 2 の問題は，当然ながら返済 義務があることだ。そして筆者が重点的に調查を行っ た村では，医療費捻出目的の借金を返済するために土 地を売るケースが少なくない，贈与はそもそもカンボ ジア農村では少ない，贈与を受けるとしても一般にご く少額一数干リエル程度一である（1 米ドル＝約 4000 リエル).

以上のリスク対処方法と比較して，サンガ八や葬儀 組合の制度上の利点は次の 3 点である。第 1 に，資産 売却と異なり資産のそしい家計でも利用できる，第2 に，借入と異なり返済義務がない，第 3 に，無利子ロー ンや贈与と異なり，親戚・交友関係にかかわらず，ど の家計でむ（とくに貧しい家計が）便益を受けられる.

(2) 支援対象の限定

葬儀組合とサンガ八の多くが支援の対象者を限定し ている。しかしその限定の度合いは一般にサンガ八で 強い、サンガ八では，17 村中 9 村が高齢者のみ， あ 
るいは貧困家庭のみを対象としている，高齢者を優遇 しているのは，ある村のリーダーによると，「高齢者 は働けないから」であるという。貧困家庭のみに支援 対象を限定する理由は，支援の必要性のより強い人を 優先する，ということにあると考えられる。しかし支 援対象外之される家計であ，そのほとんぞは決して豊 かではないので，家族が重病になったときの医療費は 非常に大きな負担である。そそ机ゆえサンガ八の支援対 象が限定されていることは, 多くの家計の苦境が見過 ごされていることを意味する.

一方，葬儀組合では，貧富に関わらずあらゆる家計 の葬儀が支援対象となる。しかし葬儀組合の一部は子 供の葬儀を対象から除外している。これは「子供の葬 式にはあまり費用をかけないから」であるという。

（3）寄付の義務化

サンガ八・葬儀組合においては，運営者が村民に寄 付を呼びかけ，それに応じて各世带は寄付を行うが， 寄付が義務となっている場合と，任意である場合とが ある．また寄付の金額も，任意の場合むあれば，寄付 の最低額が設定されている場合あある。葬儀組合の大 半で (9 村中 8 村で) は寄付が義務となっていてかっ 最低額が設定されている。 しかしサンガ八ではその 4 分の 3 以上（17 村中 13 村）で寄付が任意となってい る.

寄付を義務化したサンガ八・葬儀組合の運営者によ ると, 寄付の義務化や最低額の設定は寄付を増やすた めの策であるという。これらのサンガ八・葬儀組合む かっては寄付が任意だった。しかし各自の寄付額が少 なく，また中には寄付をしない者むいたために，寄付 が少ししか集まらなかった。 そこで寄付を義務化しか つ最低額を設定したのだという。事実, 寄付の義務化 は寄付の增加につながった，例えば，ある村では寄付 が任意の頃は 1 件あたりの寄付総額は 10 万リエルほ どであったが，寄付を義務化してからは20万リエル あ集まるようになったという。

(4) 寄付金額

1 世帯・1 件あたりの平均寄付額は（葬儀組合また はサンガ八の寄付 1 回あたり平均的寄付合計額を村の 世帯数で除した值), 葬儀組合では 1,889リエルなの に対し，サンガ八では766リエルしかない、サンガ八 の方が葬儀組合よりも寄付額が少ない原因は，すでに 示唆したように, 葬儀組合の大半で寄付が義務化され ているのに対しサンガ八の多くで寄付が任意となって いることにあるといえる，寄付の義務化が寄付金額を 増やしていることはデー夕からも示唆される. 例えば,
平均寄付額は寄付を義務化した 4 つのサンガ八では 1,396 リエルなのに対し, 寄付が任意の 13 のサンガ 八では 573 リエルしかない.

サンガ八の寄付が少ないことはその救済制度として の有効性を損なっている．例えば，カンボジアでは重 病の治療費に 50 万から 100 万リエル以上むかかるの だが, 寄付を義務化していないサンガ八では一般に 1 件につき 10 万リエルほどしか集まらない，一方，寄 付を義務化し寄付最低額を設定しているサンガ八では, 20 万〜 30 万リエルほよ゙集めている。 したがって，サ ンガ八の有効性を高める策のひとつとして, 寄付の義 務化が考えられる.

\section{3. サンガハで寄付の義務化がなされにくい理由}

(1) 給付の不確実性之寄付義務化の関係

寄付の義務化が葬儀組合ではなされサンガ八ではな されにくいことの理由を考察する. サンガ八で寄付を 義務づけるためには，何らかの条件が満たされている 必要があると考えられる，それは端的に言えば，自分 が寄付をもらう側になりやすいということであると考 えられる.このことについて説明する.

サンガ八には家計間のリスクシェアリング機能があ る.しかし少なくとも人々の認識としては，サンガ八 の趣旨は「リスクシェアリング」というよりは「困っ ている人を助けること」ないしは「救済」であるとい える. その根拠は第 1 に，上述のようにサンガ八の多 くが貧困者や高齢者といった弱者のみを支援対象して いることである．第 2 に，人々はサンガ八を通じて寄 付をむらうことを「権利」としてではなく，むしろ 「施しをうける」ことと認識しているとみられること だ、というの屯，サンガ八では，重病人（の家族）が 運営者に依頼してサンガ八を開いてもらうのではなく, 重病人がいるという噂を聞きつけた運営者が，サンガ 八を開くか否かを決定しているからだ。第 3 に，仮に サンガ八で他人にあまり寄付をしない人がいるとして あ, サンガ八での寄付の対象から外されるわけではな い. サンガ八がリスクシェアリング目的で行われてい るなら，寄付をしない者は寄付を受けられないように するはずである.

サンガ八がリスクシェアリングよりは救済制度とし て認識されていて，かつ寄付が任意であるとき，人々 が寄付をするのは純粋に困っている人を助けたいとい う利他的動機を持つからであろう。あるいはカンボジ アの大多数の人々が信仰する仏教の教えに従って徳を 積むために寄付をするのかもしれないし2，あるいは 
社会的評判を高めたいという動機で寄付をするかもし れない，したがって，[寄付が任意な場合の各人の寄 付額］は [その人の利他的動機・宗教的動機・社会的 動機に基づいて拠出される最高額了に等しいと考えら れる，すると，寄付が義務となり最低額が設定される ことで寄付が任意であったときよりあ寄付を増やさね ばならないとき，人々がこの寄付の増額に納得するた めには, 利他心の満足や社会的評判以外の便益を人々 が感じる必要があると考えられる，サンガ八を通じて 得られる利他心の満足や社会的評判以外の便益とは, 自分（の家族）が病気になったときに寄付を屯らうこ とである。したがって，自分が寄付をもらう立場にな りやすい，あるいは寄付をむらうことが確実ならば， 人々は寄付の義務化に納得しやすいと考えられる。逆 に，自分が寄付をもらうことが不確実な場合には，寄 付義務化には抵抗を感じるだろう。

この議論の意味するところは, 途上国のインフォー マルなリスクシェアリング制度が「バランスのとれた 互酬 : balanced reciprocity」に基づいている，とい うPlatteau の議論と同じである。つまり，人々は 「自らの行った貢献ないし費用負担に対して何らかの 対価を期待している」(Platteau [2]，p.764，筆者訳） ので，自分が対価を得られない場合には大きな不満を 感じてしまうというのだ。この考えに基づいて， Platteau [2] は途上国でよく見られるインフォーマ ルなリスクシェアリング制度は「バランスのとれた互 酬」の原則を満たしやすいもの，すなわち参加者が給 付を受ける確率が高いようなものである，と述べてい る. 例えば, 起こる確率の高いリスクに対する制度や, 複数のリスクを対象とする制度である。また Platteau [2] は，起こることの確実な事象一例えば 死一に対する制度，つまり葬儀組合を，やはり「バラ ンスのとれた互酬」を満たしやすくそれゆえ途上国で よく見られる制度であるとして紹介している。

以上の議論をふまえると, 葬儀組合とサンガ八の違 いは次のように説明することができる. 葬儀組合では, 葬儀，つまり死というどの家計むいつかは必ず経験す る事象に対して寄付がなされ，加貧富に関わらず対 象となるので，各家計にとって寄付を受けることは一 その時期はわからないがー確実である。それ机え葬儀 組合では人々は寄付の義務化に納得しやすいのだと考 えられる，一方サンガ八では，寄付をむらえるか否か は不確実である。重病は必ず罹るものではない，さら に上述のように多くのサンガ八は支援対象者を限定し ているので，仮に重病になってもサンガ八で寄付をも
らえるとは限らない，このように寄付を受けることが 不確実ならば，人々は寄付の義務化に消極的になるか あしれない。

事実，サンガ八でも，支援対象者の範囲が広くそれ ゆえ各自が寄付を受ける確率が相対的に高い場合には 寄付が義務化されやすい傾向がある，すなわち，支援 対象者を高齢者や貧困者に限定している 9 のサンガ八 のうち，寄付を義務化しているのは 1 つのみだが，対 象をそのように限定していない 8 のサンガ八のうち 3 つで寄付が義務化されている.

さらに支援対象者の範囲が広い方が平均寄付金額も 多い傾向がある，例えば，寄付が任意のサンガ八だけ をとっても，つまり寄付義務化の効果がない場合に限っ ても，支援対象範囲が広いサンガ八の平均寄付額は 804 リエルで，支援対象を限定しているサンガ八の 428 リルよりも多い。このことは，人々が，自分が 寄付を受ける確率が高いのでより多くの寄付をするこ とも厭わない，ということを示唆している.

以上の議論はまだ仮説的であることは否めない，し かし, 各自が寄付を受ける確率が高い方が寄付を義務 化しやすく，かつ（またその義務化のおかげで） 1 世 帯あたり寄付額が大きくなる，という可能性が充分に 考えられる.

（2）寄付義務化の障害と推進策

以上の議論を前提とすれば，サンガ八で寄付を義務 化し寄付を増やすためには，支援対象者の範囲を広げ ることが望ましい，例えば，貧困家庭だけでなく相対 的に豊かな家庭屯支援対象とする必要があるだろう。 しかし支援対象の拡大は容易ではないか屯しれない。

その理由は，第 1 に，豊かな家庭む支援対象に含め ることは「困っている人」を助けるというサンガ八の 趣旨にそぐわないことだ，第 2 に，「困った人を助け る」という趣旨でサンガ八を行う限り，サンガ八の寄 付は主に利他心や信条によって行われると考えられる ので，寄付は自発的にされるべき屯のとして受け止め られ義務化になじまないことである。事実，ある村で はそのことが理由でサンガ八の寄付を義務化しないと いう.

しかし，サンガ八での寄付義務化を促す策がないわ けではない，例えばある村では，村長が村人にサンガ 八の意義を説明し, 説得して寄付の義務化・最低額設 定を行い，寄付の増額を果たしている。 また，カンボ ジアでは互酬の規範，より正確には「受けた恩は返す」 ことが重視されているので（Kim [1]），人々に互酬 制を意識させることが功を奏することもある。例えば 
ある村では,「豊かな人は普段ほかの村人を助けてい るので，その恩を返すために豊かな家の人が病気になっ たときに村人はそれに対して支援をするべき」という 考えから，支援対象に豊かな家庭も含め，その上で寄 付を義務化したという。

\section{4. 結論}

サンガ八と葬儀組合は，葬儀費用や医療費のために 困窮した家計を助けるという救済制度として始まり, かつ運営されており, 家計の直面するリスクの負担を 軽減する機能を持っている. しかし特にサンガ八では, 支援対象が限定されているという問題，また，集まる 寄付が少ないという問題がある、サンガ八で寄付が少 ないのは，寄付やその金額が任意であることによると 考えられる.

サンガ八で寄付が義務化されにくい原因は，人々が 寄付の義務化を通じて寄付を増やすことに対価を期待 していると考えれば理解できる. サンガ八では重病と いう経験するかどうか不確実な事象を支援対象として おり，また対象者を限定する場合も多いので，自分が 寄付を受けるという形で対価を得られるかどうかが不 確実である。 それゆえ人々はサンガ八で寄付を義務化 することに抵抗を感じるものと推察さる．これに対し て葬儀組合で寄付が義務化されやすいのは, 家族の死 というどの家庭もいつかは経験する事象を支援対象と しかつ対象の限定性が小さいため, 寄付を受けること が確実なためであると考えられる。

サンガ八で寄付を増やすには, 寄付の義務付けや最 低額の設定が必要と考えられる。そして寄付義務化を 人々が受け入れやすくする上で，支援対象者の範用の 拡大が有効かもしれない。 そのためにはサンガ八の
「救済」という趣旨をトーンダウンさせて，互酬制と いう側面を強調すること，また村のリーダーが人々を 説得することが重要となるだろう.

注 1) カンボジア農村で葬儀組合やサンガ八がいつ頃から存 在しているのかは定かではない，しかし，それらが過 去の遺物で衰退の一途をたどっている，というわけで はないことは確かである。例えば，調査対象の計 27 の葬儀組合・サンガ八のうち，1975 年以前から存在 するむのは 6 つにすぎず，1980 年代に始まったもの は 9 つ，そして 12 が 1990 年以降に始められている.

2) 葬儀組合屯サンガ八む, その運営を行うのは, 村長や, アチャー之呼ばれる仏教儀式や寺の運営に関わる男性 (主に高齢者) である（カンボジアは仏教国である）。 葬儀は仏式で行われるので, 葬儀組合にアチャ一が関 わるのは自然である。しかしサンガ八であアチャーが リーダーとなる場合が多いことは，サンガ八を通じた 寄付行為が仏教でいう「徳を積む」行為として認識さ れていること，そしてそれゆえ仏教徒である村人の寄 付を集めることができる，ということを示唆している.

\section{参考文献}

[1] Kim, S., Reciprocity: informal patterns of social interactions in a Cambodia village near Angkor Park (Master thesis, Department of Anthropology, North Illinois University, 2001).

[2] Platteau, J.-P., "Mutual insurance as an elusive concept in traditional rural communities", Journal of Development Studies, Vol.33, No.6 (August 1997), pp.764-796. 